Cytogenet Genome Res 1973;12:288

\title{
Human genetic mutant cell repository
}

As a special feature, Cytogenetícs and Cell Genetics will publish in this section brief descriptions of cell cultures from individuals with chromosome aberrations. These descriptions, together with photographs of the chromosomes, are prepared by the staff of the Human Genetic Mutant Cell Repository. The cell cultures have been stored in liquid nitrogen and are available to qualified investigators.

The repository is sponsored by the National Institute of General Medical Sciences, U.S. Public Health Service, under Contract N01-GM-3-2112 to the Institute for Medical Research, Camden, New Jersey.

Requests for reprints and further information should be addressed to either Dr. Lewis L. Coriell or Dr. Arthur E. Greene, Institute for Medical Research, Copewood Street, Camden, NJ 08103 (USA). 